\title{
ACTIONS OF WOMEN FARMERS IN FAMILY CARE: USE OF MEDICINAL PLANTS IN SOUTHERN BRAZIL ${ }^{1}$
}

\author{
Ângela Roberta Alves Lima², Rita Maria Heck³, Márcia Kaster Portelina Vasconcelos ${ }^{4}$, Rosa Lía Barbieri ${ }^{5}$
}

\footnotetext{
${ }^{1}$ Extracted from the dissertation "Women farmers in family care with medicinal plants" presented to the Graduate Program in Nursing (2012), Federal University of Pelotas, UFPel, Rio Grande do Sul, RS, Brazil.

${ }^{2}$ M.Sc. in Nursing. RN. Municipal Government of Pelotas, RS, Brazil. E-mail: angelarobertalima@hotmail.com

${ }^{3}$ Ph.D. in Nursing, Associate Professor, School of Nursing, UFPel, RS, Brazil. E-mail: rmheckpillon@yahoo.com.br

${ }^{4}$ M.Sc. in Nursing, RS, Brazil. E-mail: angelarobertalima@hotmail.com

${ }^{5}$ Ph.D. in Genetics and Molecular Biology, Researcher at Brazilian Company for Agricultural Research, Embrapa (Temperate Agriculture unit), RS, Brazil. E-mail: angelarobertalima@hotmail.com
}

\begin{abstract}
The aim of this study was to describe actions in family care and use of medicinal plants by women farmers in the south of Rio Grande do Sul, RS, Brazil. This is a qualitative study with a group of 15 women farmers from District of Rincão da Cruz, Pelotas, RS. Data were collected in 2011 and 2012. Participant observations, focus groups, and individual interviews were performed, resulting in two thematic cores. The theoretical reference for this study was based on publications by Geertz and Leininger. Content analysis of discourses was developed in three stages: pre-analysis, analysis, and interpretation of results. These women were shown to have knowledge on medicinal plants and the most prevalent diseases in the region. This knowledge is used in the context of the family and community care. These women farmers are recognized in the region by their persistent work with medicinal plants as a health resource. KEYWORDS: Community health nursing. Plants, medicinal. Rural population. Unified Health System.
\end{abstract}

\section{AÇÕES DE MULHERES AGRICULTORAS NO CUIDADO FAMILIAR: USO DE PLANTAS MEDICINAIS NO SUL DO BRASIL}

RESUMO: O trabalho teve como objetivo descrever ações de cuidado familiar e uso de plantas medicinais, realizadas por mulheres agricultoras do Sul do Rio Grande do Sul. Trata-se de uma pesquisa qualitativa, envolvendo um grupo de 15 agricultoras do Distrito de Rincão da Cruz, Pelotas, RS. A coleta de dados ocorreu em 2011 e 2012. Realizaram-se observações participantes, grupo focal e entrevistas individuais, que resultaram em dois núcleos temáticos. O referencial teórico embasou-se em Geertz e Leininger. A análise de conteúdo desenvolveu-se em três etapas: pré-análise, exploração do resultado, interferência e interpretação dos resultados. Constatou-se que as mulheres possuem conhecimentos sobre as plantas medicinais e sobre as enfermidades mais recorrentes na região. Esse conhecimento é utilizado no contexto de cuidado da família e comunidade. A persistente trajetória destas mulheres agricultoras faz com que sejam reconhecidas regionalmente pelo trabalho com plantas medicinais e um recurso de saúde.

PALAVRAS CHAVE: Enfermagem em saúde comunitária. Plantas medicinais. População rural. Sistema Único de Saúde.

\section{ACCIONES DE MUJERES CAMPESINAS EN EL CUIDADO FAMILIAR: USO DE PLANTAS MEDICINALES EN EL SUR DE BRASIL}

\begin{abstract}
RESUMEN: El estudio objetivó describir las acciones de cuidado familiar y el uso de plantas medicinales por mujeres campesinas del sur del Rio Grande do Sul. Se trata de una pesquisa cualitativa, envolviendo un grupo de 15 mujeres agricultoras del Distrito de Rincão da Cruz, del área rural de Pelotas-RS. La recolección de los datos ocurrió en 2011 y 2012. Fueron realizados observación participante, grupo focal y entrevistas individuales que resultaron en dos núcleos temáticos. El referencial teórico se embazó en Geertz y Leininger. El análisis de contenido se desarrolló en tres etapas: pre-análisis, exploración de los resultados, e interferencia e interpretación de los resultados. Se constató que las mujeres tienen conocimiento acerca de las plantas medicinales y de las enfermedades más recurrentes en la región. Estos conocimientos son utilizados en el cuidado en el contexto de la familia y en la comunidad. La persistente trayectoria de las mujeres campesinas é reconocida por los residentes de la región como una fuente de salud.
\end{abstract}

PALABRAS CLAVE: Enfermería en salud comunitaria. Plantas medicinales. Población rural. Sistema Único de Salud. 


\section{INTRODUCTION}

Brazilian studies on family care in rural areas are scarce. Most of them ignore care actions with practices not related to the biomedical model. Furthermore, they do not include the ecological and cultural perspective, which would comprise the health care of families in rural areas. ${ }^{1-3}$

In addition, empirical studies highlight the role of women caregivers of patients with chronic diseases, not referring to the family routine in which health and disease alternate in a dialectical relationship. ${ }^{4-6}$ Moreover, they do not seek to understand the environment and health practices culturally established and developed by women.

In the families, women are reservoirs of traditional knowledge. They, who know the repertoire of complaints (including the discomforts of the body and soul and healing practices), retransmit this knowledge through generations, preparing and preserving medicinal plants, producing teas, ointments, and syrups for various ailments, becoming thus a reference in the family and community care. ${ }^{7}$

In general, family farming has been excluded from the global scene of transformations (in the technological, economic, social, and cultural fields) experienced by Brazilian society over the last decades. ${ }^{3}$ Because these changes did not reach these fields equally, two models of production, family and agribusiness (or technological) farming, coexist in Rio Grande do Sul. ${ }^{8}$ Such exclusion is perceived not only in the access to consumer products, but also in family care. However, the exclusion condition leads family farming to produce its own knowledge and care practices.

Autonomy of rural communities, where family farming prevails, tend to increase as they become isolated from more urbanized centers, and an intersubjective reality is then shared with other communities. ${ }^{9}$ Isolation favors strengthening of local ties and contributes to the search for solution to most of their problems among themselves.

Approximation of traditional care actions, such as use of medicinal plants, requires that the family is perceived as a complex care unit, which must be understood in the social, historical, and cultural context. Whereas such perception gives a meaning to the family, it also restricts their actions. Aiming at this approximation, this study was based on both interpretive anthropology ${ }^{10}$ and cultural care, ${ }^{11}$ valuing the actions of subjects in the collective and individual processes. In this study, we also tried to include the gender perspective as a category that was historically constructed and expressed through their values, ${ }^{13-15}$ practices, and discourses. These expressions allow us to reflect and give meaning to the social relationships. ${ }^{12}$

This approximation will allow health care professionals, especially nurses, better understanding the actual care of a part of rural families living in our country, where the official health care was not built on their needs or to address their specificities.

Continuing the studies on family care and use of medicinal plants, which have been conducted (2009-2011) by the Research Group for Rural Health and Sustainability, is another contribution of this study. However, these studies do not describe care actions of women farmers, who we have identified as the main knowledgeable about medicinal plants and family caregivers.

Therefore, the aim of this study was to describe actions of family care and use of medicinal plants by women farmers in the south of State of Rio Grande do Sul, RS, Brazil.

\section{METHOD}

This is a qualitative, exploratory, and descriptive study, linked to the project "Bioactive plants of human use by families of ecology-based farmers in southern Rio Grande do Sul State". It was conducted at the School of Nursing, Federal University of Pelotas (UFPel), RS, Brazil, in partnership with the Brazilian Agricultural Research Corporation (Embrapa, Temperate Agriculture unit). The project protocol (No. 072/2007) was approved by the local Committee for Ethics in Research (School of Medicine, UFPel, RS, Brazil).

This study was conducted in the district of Rincão da Cruz, Pelotas-RS, with a group of women farmers (15), who live in Rincão da Cruz and the Cristal, São Manoel, and Municipal Colonies, $50 \mathrm{~km}$ away from the town. In the main study, these women were characterized as being a group who knows medicinal plants and holds regular meetings without formal support from state services (such as that of rural extension). An ecological woman farmer, who advises the group monthly, was the first contact. Establishing a link with the group was slow and contacts with its members began before the project was initiated.

In the follow-up period, the monthly meetings of the group were held from March to October. Its members harmonized the period with 
much work (corn planting and peach harvesting) in the family with the school holiday period, and their meetings were discontinued during this time. The agenda of the meetings is distributed in different collective workshops in which they prepare home recipes of medicinal plants, perform manual labor (painting, crocheting, and recycling of fabrics and plastics), and discuss issues of common interest (the official health service, foods recommended for good health, leisure, and tours of interest to the group).

The field research was carried out in the periods August to October 2011 and March to June 2012. Participant observation, focus group, and individual interviews were used as techniques for data collection. The women farmers were identified by the letter $\mathrm{M}$ (for mulher, woman), the initials of their first names and their ages. Each record was identified with the date of data collection. Three participant observations (about $120 \mathrm{~min}$ ) were performed. Two meetings with the focus groups $(90 \mathrm{~min}$ ) were also performed to dramatize family care in daily life. These meetings had an average attendance of 13 women farmers. The individual interviews covered information such as age, education, residence time at the site, activities developed in the group, and time of participation in these activities. Data obtained with the participant observation and focus group techniques were recorded by the researcher, with the help of a trained grantee. The interviews were recorded and transcribed. After this material was organized, it has undergone content analysis, ${ }^{16,17}$ which was developed in three steps: pre-analysis, analysis of results, interference and interpretation of results. This allowed us to generate themes for discussion.

\section{RESULTS AND DISCUSSION}

\section{Contextualization of the group "Hope: alternative health"}

According to the report of the members of the "Hope: alternative health" group, their activities began in the 1980s, when some women of the community joined the movement of rural women workers. In 1988, this group participated in a course on use of medicinal plants in health care, promoted by a Folk woman farmer in the region. ${ }^{14}$ Since then, these women regularly organize themselves for empowerment, valuing their actions, which are developed in workshops on various topics such as handicraft, health care with medicinal plants, and food preparation and reuse. There are currently 15 women participating in the group. They conciliate their work in agriculture with other activities such as handicraft, collective production of material for household cleaning, and preparation of products from medicinal plants.

The women farmers develop a family farming, and peach cultivation is their major agricultural activity. Among the families, only that of the group coordinator participates in the ecological fair in Pelotas-RS, Brazil. Other families produce for their own subsistence selling either at wholesale or in the local cooperative. These women develop family care using medicinal plants, and this is the first health resource for their families.

Among the women interviewed (15), the youngest was 20 and the oldest 77 years. Their mean age was 57 years, and eight of them were over 60 . This information is in agreement with studies that identify older women as those who have more knowledge about health care using medicinal plants. ${ }^{9,14,17}$

The study group comprises three generations of one family and two generations of two other families. This information is consistent with that of other studies in which knowledge about health care is constructed through socialization, which begins in the family context. ${ }^{13,17}$ This context favors specialization of women in family care, and they use this knowledge for themselves and for the members of their families when necessary. ${ }^{17}$

Regarding their ancestors, five women farmers are of Brazilian origin. Four of them are of Italian and German origin, and two are of Brazilian and German origin. Each of the other interviewees are of Italian and Brazilian (1), Italian, Pomeranian, and German (1), and Pomeranian (1) origin. Only one interviewee is the product of miscegenation involving the Italian, German, Brazilian, and Portuguese ethnicities. Regarding religion, only the woman farmer descendant of Pomeranians is evangelical Protestant, whereas the others are practicing Catholic Christians.

Regarding participation in the group, the times are distributed among 22 (3), 14 (4), 10 (4), 5 (3), and 4 (1) years. Thus, the average time for participation in the group is 13 years. These women have incomplete primary (12), complete fundamental (2), and complete medium (1) education.

The district of Rincão da Cruz is located in the colonial area, municipality of Pelotas, RS, Brazil, and is one of the most representative places of 
settlement of Italian immigrants in southern Rio Grande do Sul. This location stands out because their leaders seek to broaden the mechanisms for valuing both the cultural heritage and their family goods, which may also be considered a cultural heritage. ${ }^{18}$

A coincidence was found between the beginning of group existence and important social achievements, including expansion of the official health system (creation of the Unified Health System) and pension for rural women workers. In Brazil, these achievements stem from social movements, political induction for recognition of popular health practices by the World Health Organization (WHO) since 1978, and guidance for their legitimization by the official health system. Social movements in Brazil were more evident in the mid 1980s and early 1990s, when they were supported by Non-Governmental Organizations (NGOs) and the Catholic and Lutheran Churches, showing the influence of religious organizations in the diffusion of popular knowledge, as discussed earlier. ${ }^{12}$

Recognizing the existence of other health resources in the community, beyond that offered by the official health model, it is extremely important so that professionals in this area, especially nurses, expand their knowledge and develop care actions that can meet the real needs of their communities.

\section{Care actions performed by women farmers}

In the understanding of women farmers, health directs everyday life, and a good portion of time is devoted to actions aimed at health care. These actions are built in the daily life of the family. Aiming to meet distinct demands, they seek to articulate actions such as selecting, cultivating, and organizing plants for later use. In addition, they prepare medicinal products and keep medicinal plants for the winter, anticipating the family needs. This is exemplified by what one of the women farmers said: I harvest many plants because people know that leaves fall now in the winter. I've already harvested and dried them. Now I keep them for use. I dry several teas so that I have them in the wintertime (MO57).

Such precaution involves not only the family but also other community members, ie, it covers various circles of people. The group has a network in which the families exchange knowledge about medicinal plants and products among themselves. Each woman or family group prepares medicinal products from plants most known or produced. When people in the community need medication, they look for the family indicated and receive the medicinal plant or product they need.

[...] It's like that, if I don't have it at home, I search there in the neighbors, because sometimes they have it, and it's okay (MO57).

Thus, a family does not need to have all medicinal plants, because they may resort to a neighboring family, when necessary.

From our data, we can state that women are responsible for the production, selection, and preparation of the food consumed by the family. Among their care with production, we highlight the reduction in the use of pesticides and hormones. In order to achieve this goal, the families produce their own food and raise animals, which will be slaughtered for the consumption of both fresh and processed meat. Legumes and vegetables are grown organically, apart from tillage, which is intended for sale. The same is done with medicinal plants.

We raise our animals with what people plant and eat; we plant corn and give it to chickens, to pigs. Everything comes from home. They don't take medicine, don't take anything (agrochemicals) (MM60).

The good thing is not putting bad thing in the vegetable garden (MD29).

We can keep our vegetable garden without pesticide. However, taking care of it is also necessary, as people won't make tea with pesticide (MRR45).

These data confirm other studies that indicate another rural lifestyle emerging in Brazil. Such lifestyle does not come from a government project, but from the daily life of farmers who seek to consume and produce foods that cause less damage to health. ${ }^{8}$

In this production model, women have been identified as the main agents responsible for the introduction and maintenance of this form of plant cultivation and animal management in their families. They seek to maintain a space near their homes for the production of organic foods that will be consumed by households. ${ }^{7,19}$

Medicinal plants are also used as food to both prevent health problems and reduce the need for medication. Women use this knowledge to promote health in the family. As they are responsible for the selection and preparation of food consumed in the house, they introduce dietary medicinal plants, vegetables, and fruits that they recognize as being beneficial to health. As an example of this, 
we have the speech of two women farmers: Alcina makes hormone replacement, although it is a plague in the vegetable garden. Verduega and blessing of God have much iron, and can be used as salad (MR63).

[...] the body also gets used to, and medication drops to half (MO46).

Women recognize that diet care is important to prevent chronic degenerative diseases, such as diabetes and hypertension. Thus, this group of women seeks to provide their families with a diverse diet, including fruits, green vegetables, and legumes, prepared with less sugar and sodium. Recognition that use of pesticides in agriculture and hormones in livestock is harmful to health is also highlighted. These food-related actions are also seen as a form of domestic economy, because the meals are prepared with less cost, thus helping to prevent disease and reduce drug expenditures.

[...] I think caring for fat and salt is very important; the less sugar I give, the better for them. Thus, at least I always take care to don't get sick (MD29).

As can be observed in the speeches above, the women who participate in the group know the measures of health care and prevention that come from the official health care system. They were probably acquired through their experiences of care with either themselves or other members of their families. This knowledge is associated with care provided with the use of plants. Such association, which brings the herbal and allopathic care together, is termed cultural care, ${ }^{11}$ as it combines the professional and family health systems. This can be confirmed by the speech below.

At home, they also go right for the Malva, they take it every six hours, and it heals right away when there's any sore throat. However, if it's much advanced, it may not resolve (MSL60).

Women have a set of knowing, which is reflected in the form of family care. Such knowing is constructed through socialization, and it is under continuous renegotiation. This set of knowing and practices is formed from the union of knowing about both the official model of health and traditional medicine. Each of these systems offers different therapeutic resources, such as allopathic medication, medicinal plants, and traditional medicine practices. ${ }^{9}$

Although these women farmers prepare phytotherapeutic products using association of plants, they are cautious in not using toxic plants in their preparation. This comes from their experience of use, exchange of knowing with previous genera- tions, and interaction in the current social living, as observed in the following speech:

[...] no, in the syrup, we don't use toxic plants, but all the aromatic ones; honey, we put it after tea is ready (MR63).

This popular knowledge survived due to economic difficulties and difficulty in the access to health services. Both difficulties favored the search for other resources, which enabled family care.

Herbal medicine survived only because there were few resources; it was necessary to use the herbs. They were the only escape (MR63).

In ancient times, there was no pharmacy. Our ancestors went into the woods when they came from Italy. They lived from nature given by God (MOP65).

Currently, many people have sought the use of medicinal herbs in health care, using them in a way complementary to the treatment proposed by biomedicine. These groups exchange information between them, diffusing knowledge about medicinal herbs. This process can also be confirmed by the study group, as observed in the following report: due to the groups who work and exchange knowledge about plants, the use of St John's wort is a thing that happened and is working very well. A laboratory is already studying and thinking about production of a drug based on this herb (MMR63).

Among the reasons alleged for the growing use of complementary therapies, especially the use of medicinal plants in health care, we highlight the following ones. The feeling that traditional medicine has failed to provide effective solutions to health problems of the population; users' need to play a more active role in their health-disease process, and; the ecological awareness, which emerged after the 1990s, contributed to the search for other forms of care with less environmental impact. ${ }^{20-21}$

The study group combines the use of herbal and allopathic medicines in health care. With this combination, they seek to solve their health problems and those of their families so that they do not have to refer to the health service. This observation is in agreement with other studies, ${ }^{22-23}$ which highlight the autonomy of residents in rural areas in the care [of their health]. They resort to the health service only when its resources cannot solve their problem. Such behavior makes their cases urgent, since the health service is not the first resource they seek.

Medicinal plants are not only considered by them equally or more effective than allopathic 
medication, but also the first resource they seek, being yet utilized to reduce the use of industrial medication. (MC64).

For us, plants are better than pharmacy drug

The explanation for this form of care could be that this group seeks to act when the pathological processes are already established, taking plant-derived products to restore the organic balance, believing that such products will not allow processes to worsen or become chronic.

Our data show that these women perform various activities inside and outside their homes. Their care actions include their own homes, small animals, vegetable gardens, education of children, tillage work, disease-prevention activities, and general assistance when someone in the family or neighborhood needs.

Women's life in the swidden is agitated and tense. Behind this, women do a lot of little things in the house, which go unnoticed. For instance, we take care of home, children, vegetable garden, animals, because there are various animals in the colony, give attention to the husband, and make food (MR63).

We have observed that the care actions in this group are focused on the possibilities, beliefs, and values, thus contributing to treatment adherence and leading to an active participation during the care process. For this purpose, women seek support from each other through participation in community groups. The scenario of participation of these groups is a fruitful space for exchange of experiences, mutual learning, and development of cultural care.

This information is in agreement with the literature, which highlights women as precursors within the family unit, in which they accept the interior challenge of implementing something new. While challenging the conventional production, they introduce knowledge from other generations and interact with other groups. ${ }^{4,7}$ However, they perceive their actions as invisible to the society, as can be seen in the statement below:

[...] women's work isn't very visible, that of men is visible, any type of work they do is visible. Yet, that of women isn't visible. However, women are just now working hard there with the peaches (MR63).

This is because women's work, when performed outside the home environment, is considered as an aid, a complement to the activities in the countryside. ${ }^{24-25}$ Indeed, even today the activities that generate the highest incomes are declared and paid on behalf of men, e.g., bills of sale of milk in local cooperatives. We also highlight that activities performed by women in their homes are not considered work, but an obligation and/ or demonstration of affection and care for the family, something that is inherent in their female condition. ${ }^{25-26}$

Our data indicate that this condition is enhanced by the women themselves. They assume this condition for themselves, because they are prepared for it better than men are, and consider themselves responsible for the care in the family. This condition is regarded as a mission assigned by God and inherent to the gender, not as something culturally established, as can be seen in the speech below:

[...] I think it's something given by God as we are women. We have generated these children, we love them so much, we take care of them, and we always want them to have the best. As we know tea and these other things are good, we try to give them first (MM60).

We believe that the scenario of participation in the group becomes an important space, not only for exchange of knowledge and preservation of local culture, but also because it allows breaking the cycle of male domination and invisibility of the work of rural women. This happens from challenging by younger generations and group discussions, which allow for reflection on the activities of rural women.

Such participation contributes so that these women can better visualize their actions, not reproducing this cycle while raising their children. Continuous participation in these group activities may lead to slow changes in the family, but can bring tangible results in the long term. Moreover, their participation in such activities favors a better view of women's work by the local community, who assigns a higher value to it when the additional component of health resort is recognized.

\section{FINAL CONSIDERATIONS}

Survey of care actions by women farmers allowed knowing their cultural care habits, in which use of medicinal plants or herbal-based preparations are the first resource.

Medicinal plants are viewed as an environmental resource of female domain for use in situations of varying severity, not only for their low cost, but also because they are believed to be the best health resource due to the smaller side effects they cause. 
In the study context, women farmers showed to know medicinal plants and the most frequent diseases in the region, using this knowledge in health care within the family structure and in the community. For this reason, they are recognized to be a health resource by residents in the region, who seek their assistance in case of illness.

The women farmers select, cultivate, and organize these plants, preparing them for use and storage in periods when medicinal plants are not found in nature. They use an exchange system that allows families to have access to the medicinal plants they need.

Our results render elements for discussion with a view to both family care and appreciation of popular knowledge. Especially, this knowledge could be included among the tools of health professionals who work in the biomedical model.

Regarding nursing, it is important to recognize that herbal-based care actions in the family nucleus are effective, allowing these families to have better health conditions. This understanding is essential for a culturally-sensitive care, enabling expansion of practices in health care. This knowledge must be built together with the community, allowing their interpretations and meanings regarding care with use of medicinal plants to be included.

This study highlighted care as seen by women. Therefore, although the care actions in the family presented herein have focused those performed by women, a comprehensive understanding of these actions is necessary, deserving further studies to expand this knowledge.

\section{REFERENCES}

1. Fernandes GCM, Boehs AE. A família rural em fases de transição: mudanças nos papéis e tarefas do cuidado familiar. Cogitare Enferm. 2010 Jan-Mar; 15(1):33-9.

2. Badke MR, Budó MLD, Silva FM, Ressel LB. Plantas medicinais na prática do cotidiano popular. Esc Anna Nery. 2011 Jan-Mar; 15(1):132-9.

3. Zillmer JGV, Schawartz E, Ceolin T, Heck RM. A família rural na contemporaneidade: um desafio para a enfermagem. Rev Enferm UFPE [online]. 2009 [acesso 2011 Set 09]; 3(3):319-24. Disponível em: http://www.ufpe.br/revistaenfermagem/index. $\mathrm{php} /$ revista/article/view/1640

4. Leite SN, Vasconcelos MPC. Negociando fronteiras entre cultura, doença e tratamento no cotidiano familiar. Hist Cienc Saúde-Manguinhos. 2006; 13(1):113-28.
5. Serapioni M. O papel da família e das redes primárias na reestruturação das políticas sociais. Cienc Saude Coletiva. [online]. 2005 [acesso 2011 Jul 26]; Disponível em http://www.scielosp.org/scielo.php?script=sci_ pdf\&pid=S141381232005000500025\&lng = en\&nrm=iso\&tlng=pt

6. Garcia-Calvente MM, Mateo-Rodríguez I, Eguigurem AP. El sistema informal de cuidados en clave de desigualdad. Gac Sanit. 2004; 18(1):132-9.

7. Karam KF. A mulher na agricultura orgânica e em novas ruralidades. Rev Estud Fem. 2004 Jan-Abr; 12(1):303-20.

8. Brandemburg A. Do rural tradicional ao rural sócio ambiental. Rev Amb Soc. 2010; Jul-Dez; XIII(2):417-28.

9. Tezoquipa IH, Monrealm LA, Santiago RV. El cuidado a la salud en el ámbito doméstico: interacción social y vida cotidiana. Rev Saúde Pública. 2001; 35(5):443-50.

10. Geertz C. A interpretação das culturas. 13 reimp. Rio de Janeiro (RJ): LTC; 2008.

11. Leininger M. Culture Care Theory: a major contribution to advance transcultural nursing knowledge and practices. J Transcult Nurs. 2002 Jul; 13(3):189-92.

12. Scott J. Gênero: uma categoria útil de análise histórica. Ed Real;1990.

13. Ceolin T, Heck RM, Barbieri RL, Schwartz E, Muniz RM, Pillon CN. Plantas medicinais: transmissão do conhecimento nas famílias de agricultores de base ecológica no Sul do RS. Rev Esc Enferm USP. 2011 Mar; 45(1):47-54.

14. Lopes CV. Informantes Folk em plantas medicinais no sul do Brasil: contribuições para enfermagem [dissertação]. Pelotas (RS): Universidade Federal de Pelotas. Programa de Pós-Graduação em Enfermagem; 2010.

15. Lima ARA, Vasconcelos AKP, Barbieri RL. Plantas medicinais utilizadas pelos octogenários e nonagenários de uma vila periférica de Rio Grande/ RS, Brasil. Rev Enf UFPE [online]. 2011 [acesso 2011 Set 09]; 5:1319-26. Disponível em: http://www. alice.cnptia.embrapa.br/bitstream/doc/910148/1/ artigopublicadoplantasmedicinaisxoctagenarios.pdf

16. Triviños ANS. Introdução à pesquisa em ciências sociais: a pesquisa qualitativa em educação. São Paulo (SP): Atlas; 2008.

17. Menéndez EL. Modelos de atención de los padecimientos: de exclusiones teóricas y articulaciones prácticas. Ciênc Saúde Coletiva. 2003 Jan; 8(1):185-207.

18. Pains M. Turismo, patrimônio cultural e desenvolvimento local: o distrito de Rincão da Cruz no município de Pelotas/RS [dissertação]. Campinas (SP): Universidade Estadual de Campinas. Programa de Pós-Graduação em Geografia, Análise Ambiental e Dinâmica Territorial; 2009. 
19. Freire P. Gênero e saberes da Amazônia: reflexões sobre saúde e conhecimentos tradicionais; Rev Fazendo Gênero. 2008 Ago; 8(1):2-10.

20. Viveiros AAS, Goulart PF, Alvim NAT. A influência dos meios sociocultural e científico no uso de plantas medicinais por estudantes universitários da área da saúde. Esc. Anna Nery Rev Enferm. 2004 Abr; 8(1):62-70.

21. Arnold E, Clark EC, Toby LJ, Taixiang W. Intervenciones herbarias para el asma crónica en adultos y niños. Reproducción de una revisión Cochrane, traducida y publicada en La Biblioteca Cochrane Plus [online]. 2008 [acesso 12 Set 2011]. Diponível em: http://www. update-software.com/BCP/BCPGetDocument. asp?DocumentID=CD005989 Winter CA, Lee HJ, editores. Rural nursing: conceptions, theory and pratice. New York: Spring; 2010

22. Budó MLD, Saupe R. Modos de cuidar em comunidades rurais: a cultura permeando o cuidado de enfermagem. Texto Contexto Enferm. 2005 AbrJun; 14(2):177-85.

23. Fiuza ALC, Pinto NMA, Galinari TN, Barros VAM. Difusão de tecnologia e sexismo nas Ciências Agrárias. Cienc Rural [online]. 2009 [acesso 2011 Set 10]; 39(9) Disponível em: http://dx.doi. org/10.1590/S0103-84782009005000224

24. Ortner SB. Está a mulher para o homem como a natureza para a cultura? In: Rosaldo M, Louis L. A mulher, a cultura e a sociedade; Rio de Janeiro (RJ): Paz e Terra; 1979. p. 95-120.

25. Noronha OM. De camponesa a madame. São Paulo (SP): Loyola; 1986 